\title{
A natureza poética da espiritualidade não religiosa: Um olhar a partir de Jean Paul Sartre
}

\author{
The poetic nature of non-religious Spirituality:
}

A point of view by Jean Paul Sartre

Alex Villas Boas Oliveira Mariano*

\begin{abstract}
Resumo
A proposta deste artigo é analisar algumas teorias de espiritualidade não religiosa sob o ângulo do fenômeno crescente daqueles denominados como "sem religião" pelo Censo religioso brasileiro realizado em 2010 pelo Instituto Brasileiro de Geografia e Estatística (IBGE). Pretende-se então identificar como a questão poética se apresenta como elemento fundante destas propostas de espiritualidade em autores, na medida em que a beleza é parte da busca espiritual, como em: Viktor Frankl e sua religiosidade existencial de busca de sentido para a vida; Marià Corbí e sua espiritualidade não religiosa ou espiritualidade laica; Robert Solomon e sua espiritualidade para céticos, e; André ComteSponville e sua espiritualidade ateía, ou seja, espiritualidade sem deus. Em todas essas propostas o elemento poético da espiritualidade está de alguma maneira presente. A partir daí, então, iremos apresentar a percepção da espiritualidade contida na poesia no pensamento de Jean Paul Sartre, fundamentalmente da sua obra O que é a Literatura?
\end{abstract}

Palavras-chave: espiritualidades não religiosas; mística e poesia; Jean Paul Sartre.

\begin{abstract}
This article proposes to examine some theories of non-religious spirituality in light of the growing phenomenon of those individuals who declared themselves as having "no religion" by Brazilian religious census conducted in 2010 by the Brazilian Institute of Geography and Statistics (IBGE). The intention here is to identify how the poetic question presents itself as the fundamental element of these proposals about spirituality for authors, since beauty is part of the spiritual quest, as in: Viktor Frankl and existential religiosity grounded in the search for meaning in life; Marià Corbi and his non-religious or secular spirituality; Robert Solomon and his spirituality for skeptics, and André Comte-Sponville and his atheistic spirituality, or spirituality without God. Otherwise the poetic element is present in all aucthors. From there, we then present the perception of spirituality in the poetry of the thought of Jean Paul Sartre, primarily in his work "what is Literature?"
\end{abstract}

Keywords: non-religious spirituality; mystic and poetry; Jean Paul Sartre.

Artigo recebido em 30 de junho de 2014 e aprovado em 23 de Setembro de 2014.

* Doutor em Teologia. Professor na Pontifía Universidade Católica de São Paulo (PUC/SP). País de origem: Brail. E-mail: avmariano@pucsp.br. 


\section{Introdução}

O presente artigo pretende analisar quatro propostas de espiritualidade não religiosa, em que em ambos os autores há uma percepção de espiritualidade que contempla o que aqui se chamará de natureza poética na medida em que a espiritualidade busca um excesso de sentido apesar do absurdo do mundo, que pode se desvelar na poesia e na arte (Frankl), um Absoluto silencioso que o mito e o símbolo desvela ao desejo de ir além da contingência humana (Corbí), uma paixão insistente na vida que se desvela na poeticidade multiforme (Solomon), uma beleza escondida na imanencidade do mundo (Comte-Sponville).

Após breve apresentação do fenômeno religioso dos sem religião, será apresentado quatro grandes autores que se propõe a teorizar a questão da espiritualidade sem religião, para em um segundo momento se evidenciar como a espiritualidade pode ser entendida a partir de uma natureza poética em tais autores. Mediante esta ligação entre a busca de espiritualidade e a beleza possível da vida a ser descoberta, se propõe aqui uma leitura de Jean Paul Sartre (19051980) sobre a relação que estabelece entre místicos e poetas, e o papel que a literatura tem de dar sentido à vida presente especialmente em seu trabalho, e deste modo melhor elucidar o papel da poesia na espiritualidade.

Os autores elegidos são: A proposta de Viktor Frankl (1905-1997) que elabora uma espiritualidade de busca de sentido da vida baseando-se em sua logoteoria, e na sua experiência de sobrevivente de três campos de concentração; Marià Corbí (1932), um pensador catalão e diretor do CETR - Centro de Estudos de Tradições de Sabedoria e, certamente, um dos nomes mais importantes para teorização de uma espiritualidade sem religião, ou como ele mesmo apresenta uma espiritualidade laica, sem crenças, sem religião e sem deuses (CORBÍ, 2010a) ou ainda uma religião sem religião (CORBÍ, 1996); Robert Solomon (1942-2007), que foi professor de filosofia na Universidade do Texas, propõe uma Espiritualidade para céticos (2003), em que sua relação com a crença no “Deus judaico-cristão- 
islâmico" também não é de combate, mas de ceticismo em relação a um "conjunto de ideias institucionalmente sancionadas", como prova única da "verdade absoluta" das mesmas (SOLOMON, 2003, p. 19); André Comte Sponville (1952), filósofo francês que se intitula como ateu, talvez tenha a proposta que mais levou a sério a questão de uma recusa total da religião ao advogar a necessidade de uma espiritualidade ateia, ou seja, sem Deus (COMTE-SPONVILLE, 2007). Não se trata de um ateísmo combativo às religiões, mas de uma espiritualidade que não é tributária das tradições religiosas, e que procura afirmar o espírito humano como aquela parte da matéria que se volta sobre si e é capaz de encontrar a beleza de um Todo uno, uma abertura ao universal.

Deste modo, ao se pensar na natureza poética das espiritualidades, de modo geral, há que se olhar para as tradições religiosas como formas de elaborar sabedorias de vida, sendo seus textos fundadores de perspectivas humanizadoras, e não legitimadores de fundamentalismos. Sendo este problema contemporâneo, o do fundamentalismo, muito mais ligado ao olhar de quem olha do que ao que se olha. E nesse sentido, as espiritualidades não religiosas resgatam a ideia de espiritualidade como patrimônio cultural e não propriedade de instituições religiosas, ao mesmo tempo que permitem revisitar as tradições religiosas a partir das inquietações do indivíduo contemporâneo, bem como podem dinamizar as posturas institucionais. Neste sentido, o filósofo francês se nos parece um autor insuspeito para resgatar a importância da espiritualidade na cultura, que longe de ter morrido em uma sociedade laica, se esconde na capacidade humana de poetizar a vida, tarefa comum de espiritualidades religiosas e não religiosas, e assim sendo, fonte de diálogo.

\section{A questão do fenômeno dos "sem religião"}

A questão das chamadas espiritualidades não-religiosas é um fenômeno amplo, crescente e que começa a ganhar consistência teórica. A expressão 
“espiritualidade não religiosa" ou espiritualidade dos "sem religião" pode por vezes não fazer jus a complexidade do agrupamento que atinge a cifra de 15 milhões de brasileiros e corresponde a 8,0\% da população segundo o censo de 2010 (IBGE, 2010). Vale dizer que no uso da expressão não há uma distinção clara entre religião e igreja ou instituição religiosa (LUCKMANN, 2014, p. 39-48), havendo diversas classificações subgrupais como os "sem religião": sincréticos, por circular livremente em várias tradições religiosas sem estabelecer vínculo com quaisquer instituição; em trânsito religioso ou aqueles que abandonaram uma religião e ficam "sem religião" até se identificarem com uma nova confissão, podendo mesmo participar de duas ou mais confissões neste interim; céticos, que diz respeito a um desinteresse e desencanto em relação a instituição religiosa, podendo ser o efeito de experiências de mobilidade religiosa; agnósticos, constituídos pela recusa de uma forma nominal inteligível de Deus, ou ainda como crente apenas em Deus, dispensando demais símbolos ou doutrinas religiosas, e por fim; ateus, não somente sem religião, mas sem crença em Deus (VILLASENOR, 2013, p. 37-60). Estes dois últimos subgrupos correspondem ao menor percentual dos "sem religião" no Brasil, sendo ambos representados em 0,4\%, ou seja, 763 mil pessoas (RIBEIRO, 2013, p. 6).

Assim, no caso brasileiro o substrato semântico do termo "sem religião" contempla mais expressivamente um caráter anti-institucional, do que um recusa religiosa. Deste modo a "espiritualidade não religiosa" diria respeito, na verdade, a espiritualidade sem vínculo institucional, ou ainda como espiritualidade sem igreja, ou apesar da igreja quer seja por não adesão, ou por ruptura/transito institucional. Dito desta maneira, no cenário brasileiro há pouca incidência de uma espiritualidade laica strictu sensu, prevalecendo a busca pela espiritual entendido, porém com uma postura crítica ao modus operandi das instituições religiosas, principalmente pelo ato de desligamento. Melhor tipificados, os "sem religião" em sua maioria são advindos do catolicismo (RIBEIRO, 2013, p. 3) e o período de maior evasão na igreja católica, ao menos como constatado pelo IBGE, se dá entre os anos de 1991 a 2000, em que se registra um aumento de 2,5 pontos percentuais 
(de 4,8 para 7,3\%) em relação ao crescimento de 0,7\% entre 2000 e 2010. Já entre os evangélicos o percentual de desvinculação institucional cresceu de 4\% para 14\%, entre os anos de 2003 e 2009, totalizando 4 milhões de brasileiros (GOIS; SCHWARTSMANN, 2011). Em ambos os casos, e quais sejam as classificações subgrupais há um descontentamento institucional como fator preponderante.

Vale destacar, contudo, que em meio aos "sem religião" é possível encontrar uma “cultura secular”, mais propriamente dito, em meio a população universitária, enquanto é constituída de um grupo que se caracteriza por um "distanciamento crítico”, sendo a religião vista como uma entre outras agências de sentido, e não necessariamente diz respeito a uma conformidade institucional no modo de vivenciá-la, sendo mais adequado falar de fé ou religiosidade ao invés de religião nesse meio, quando é o caso. Nesse grupo, a religião é valorizada por oferecer sentido à vida, fé, solidariedade, melhoria ética e criticada por realizarem "lavagem cerebral", manipulação emocional e apelo irracional que induz ao "fanatismo" e outras formas de "alienação" da realidade, não sem criticar a exploração financeira. Tal postura parece condizer com o maior nível de capital cultural do grupo (RIBEIRO, 2013, p. 7).

Por fim, a questão do fenômeno dos "sem religião" no caso brasileiro parece indicar menos uma postura de ateísmo, se levar em consideração os 7,6\% do caso italiano, por exemplo (FERRARI apud VILLASENOR, 2013, p. 57), e mais uma crise das instituições religiosas no seu modo de ser e pensar com dificuldade de assimilar de modo satisfatório a mudança de época que se impõe na história. $\mathrm{O}$ crescimento do decréscimo confessional das tradições antigas, bem como da desvinculação das novas formas religiosas, de modo especial do pentecostalismo, indica, salvo melhor juízo, uma ainda tímida, porém, crescente consciência do indivíduo como sujeito de decisões e em busca de autenticidade, que resulta na possibilidade de abertura a experiências religiosas configuradoras de sentido sem abdicar de um senso crítico, mais ou menos esclarecido, porém manifesto na atitude de abandono de um vínculo institucional motivado pela recusa das 
contradições, arbitrariedades, anacronismo das instituições geradoras de segregação, preconceitos e manipulações de inúmeras formas.

Tal movimento sugere uma recusa de infantilismo e menoridade por parte dos fiéis, em que este passa de objeto das instituições a sujeito crítico, no qual a pertinência do discurso sobre as questões concretas da vida parece ser o ponto de aceitação ou recusa. Nesse sentido, os "sem religião" acenam para o fato de que a crise religiosa faz parte da chamada crise das instituições, e sua inabilidade em desvincular-se de um modus operandi em que os interesses institucionais estão acima da legítima preocupação com seu destinatário (DUBET, 2002, p. 83).

\section{As propostas de teorização de uma espiritualidade não religiosa}

Elegeu-se aqui quatro grandes autores que propõem alguma reflexão sobre a emergência do sagrado, não necessariamente institucionalizado.

Viktor Frankl é o fundador da logoterapia. O Logos para o pensador vienense é maior que a lógica e se manifesta como o Humano do humano, aquilo que dá sentido à vida, pessoalmente (ad personam) e em situações concretas (ad situationem). No conceito de patodiceia frankliana coincide tanto a questão do desocultamento heideggeriano e a consciência trágica nietzschiana, constitutivas daquilo que o autor chamou de otimismo trágico, enquanto capacidade humana de dar sentido à vida apesar da tragédia, e passa a viver a existência em dinâmica de consumação, tendo como efeito a realização de um sentido. Este é um mistério ainda maior que o absurdo da morte, o de que apesar de absurda, a vida pode encontrar um sentido, presente em tudo aquilo que expressa essa dimensão, a poesia, arte, música, valores, sendo a capacidade humana de dar sentido à vida, ou de responder [diké] às inquietações internas [pathos] que despertam a vontade de sentido, sua espiritualidade. Assim, o ser humano não é "livre de" seus condicionamentos, mas tem a "liberdade última de assumir uma atitude alternativa frente às condições dadas": 
Não preciso de que ninguém me chame a atenção para a condicionalidade do homem: - afinal de contas, eu sou especialista em duas matérias, neurologia e psiquiatria, e nessa qualidade sei muito bem da condicionalidade biopsicológica do homem. Acontece, porém, que não sou apenas especialista em duas matérias, sou também, sobrevivente de quatro campos de concentração, e por isso também sei perfeitamente até onde vai a liberdade do homem, que é capaz de se elevar acima de toda a sua condicionalidade e de resistir às mais rigorosas e duras condições e circunstâncias, escorando-se naquela força que costumo denominar de poder de resistência do espírito (FRANKL, 2005, p. 41; 2004, p. 66).

Para o pensador vienense, a liberdade humana reside na capacidade de desprender-se de si mesmo e ir ao encontro de sua vontade de sentido. Isso constitui a "essência propriamente dita da existência humana" (FRANKL, 2003, p.159). Tal liberdade tem início na consciência, dimensão espiritual ou noética, que funciona como um "órgão de sentido" e um fenômeno primário, ou seja, é prélógica, e se revela como essencialmente "intuitiva", por estar imersa no inconsciente sendo seu prolongamento. Tal como o eros, o ethos é intuitivo e somente depois é passível de racionalização. A consciência é um "instinto ético", tal qual uma "consciência artística" que opera por um "inconsciente estético". A "intuição" é uma antecipação do espírito humano do que pode vir a ser e opera como "inspiração" no qual se produz a "voz da consciência" (FRANKL, 2004, p. 2668). Semelhante ao processo psicanalítico da neurose, quando o inconsciente (Id) irrompe na consciência (Ego), a "consciência", na logoteoria, se dá no momento em que o eu (espiritual) penetra o "inconsciente" e deixa emergir seus sentimentos mais profundos. Assim, a existência propriamente humana é a existência espiritual ou ainda autotranscendência, enquanto a pessoa "interiormente" pode ser mais forte que seu condicionamentos "externos", e crescer para além de si mesmo (FRANKL, 2005, p.68-72).

Para as religiões há um Emissor dessa "voz da consciência", enquanto presença desconhecida, e utilizam-se de símbolos para exprimir tal Mistério. O autor não pretende tratar de "Deus", mas da capacidade de transpor limites como sendo imanente ao ser humano, uma característica ontológica. Pelo homo religious a relação com a transcendência é um diálogo no qual o transcendente é um "Tu”, 
entretanto, para o "irreligioso" sua consciência é uma facticidade psicológica, uma realidade imanente, que não se pergunta se há algo ulterior a ela. Para este, a consciência é a última instância perante a qual precisa ser responsável, já para aquele é a penúltima, pois, há algo/Alguém além da facticidade. No entanto, o fato de ser irreligioso, não significa que não tenha consciência, ou responsabilidade, apenas não pergunta “de onde vem a consciência”, o que não deve ser motivo de inimizades entre um e outro, pois a liberdade humana de escolher seu próprio caminho, em qualquer circunstância deve ser respeitada (FRANKL, 2004, p. 4243). Independente de como é chamado: “O acesso a Deus só pode ser encontrado a partir do homem. Se tivermos de indicar a outro o caminho que leva a Deus, não podemos tomar por base o racional, mas o emocional” (FRANKL, 2004, p. 274). A religiosidade, portanto, é inerente ao ser humano enquanto crer que a vida tem um sentido, e quem o busca, já é de algum modo "religioso", mesmo sem religião. Frankl não nega o papel das tradições religiosas, porém defende a "personalização" da religião e critica as “estreitas concepções de Deus”. A religião só é pertinente enquanto impulsiona essa humanização do humano conduzindo a uma liberdade livre (FRANKL, 2004, p. 59-63).

A proposta de Marià Corbí reside sobre uma epistemologia axiológica enquanto analisa a questão do valor como fenômeno social e cultural, sendo a tarefa desta formular padrões de interpretação e avaliação do que se "tem que pensar, sentir, organizar e agir” e assim se constitui como referencial programático da realidade. Tais padrões de interpretação estruturam ações centrais de grupos humanos e se expressam em metáforas igualmente centrais que atuam como paradigma referencial. Na medida em que se organizam como paradigmas centrais, a mesma metáfora serve tanto para a interpretação e avaliação da realidade ao mesmo tempo que serve para "representar", "conceber" e "dar forma ao sentir da dimensão absoluta". Há uma inerente relação entre a semântica e a pragmática humana, constituindo assim uma ordem que estrutura a realidade tal qual é concebida em um plano divino, passando a ser este o fundamento social. (CORBÍ 2010a, p. 122; RIBEIRO, 2012, p. 4). Aqui entra o papel das religiões nas sociedades pré-industriais, enquanto estruturam a partir do mito os processos 
linguísticos (metáforas centrais), e consequentemente as práticas sociais, sendo a espiritualidade, ao mesmo tempo, experiência do absoluto da realidade e integradora ou ordenadora da estruturação social. Nesse sentido, se nos parece que para o autor, a experiência religiosa nas sociedades agrárias resulta em uma possibilidade de assimilação da ordem social, sendo a religião, portanto, a principal autoridade social e legitimadora da ordem, na medida em que elabora uma epistemologia mítica que produzem crenças imbuídas de costumes (CORBÍ, 2010a, p. 126).

O mito se apresenta como fala constituinte na medida em que é uma mediação linguística orientadora do desejo, possibilitando sua interiorização semântico-simbólica que resulta em uma ordenação intersubjetiva, ou seja, estrutura as relações sociais desde o mais íntimo dos indivíduos (CORBÍ, 1983, p. 36). Entretanto, sendo o ser humano concebido como desfundado, ou seja, em sua condição radical de ausência de fundamento pré-definido, com a mudança de paradigma das sociedades agrárias para industriais, os mitos deixam de ser fundamentos suficientes para as novas formas de organização coletiva e individual, passando as ideologias a cumprirem seu papel, especialmente a bipolaridade entre capitalismo e socialismo.

Com as sociedades de inovação há novas motivações oriundas das mudanças organizacionais e inevitavelmente comunicacionais, ou seja, novas subjetividades, enquanto um "estrutura de desejos, temores, recordações e expectativas" (CORBÍ, 2010b). Uma vez que nessas sociedades não vigora o imobilismo, mas a mudança, há que se ter uma disposição de constante interpretação da realidade, face as novas situações que geram incertezas e inseguranças, exigindo uma construção contínua de projetos axiológicos coletivos que renunciem as posturas de controle social. O indivíduo não se adequa a ordem social por cumprir um preceito, mas pela capacidade de adaptação, o que exige um novo modo de pensar, sentir e agir. Deste modo a espiritualidade laica em Corbí, diz respeito a tarefa de extrair das antigas tradições seu legado, suas sabedorias que podem ajudar o indivíduo a fazer a 
experiência do absoluto em meio a um mundo instável, porém tal legado precisa ser depurado de sua epistemologia mítica que define o modo de ser, para serem lidas como metáforas, grandes poemas sem crenças, a partir da capacidade que têm de oferecer uma qualidade humana profunda e sobretudo a capacidade de conduzir a um caminho interior, de descoberta do inefável, de um conhecimento silencioso do absoluto, como puro dom e pura presença que a ninguém pertence ou tem o direito sobre tal dimensão (CORBÍ, 2010a, p. 253). Tal legado pode ajudar a provocar o interesse pela espiritualidade, produzindo um desapego de si e dos bens finitos e um silenciamento que é um concentrar-se para descentrar-se no Outro e nos outros. A via do silêncio é um caminho da unidade e do amor incondicional a todos os seres, oferecendo outro padrão de interpretação e valoração a estrutura de desejos e temores (uma vez que todo desejo é inseparável de seu temor) que gera inquietação e sofrimento (CORBÍ, 2010b).

Solomon em sua postura cética propõe que é "necessário ser religioso" e muito menos "pertencer a uma religião organizada” para ser espiritual, pois não raro, há inúmeras pessoas adeptas de religiões que "se afirmam e se acreditam devotas, mas são tão desprovidas de espiritualidade quanto um copo vazio”. A busca do autor é de um "sentido não-religioso", "não-institucional”, "nãoteológico”, “não baseado em escrituras”, que "não seja farisaico”, "não seja dogmático", "não seja anticiência”, "não seja acrítico, carola ou pervertido" (SOLOMON, 2003, p. 19). Deste modo, propõe uma espiritualidade naturalizada que se caracteriza como um interesse apaixonado no "aqui-e-agora", dispensando a dimensão sobrenatural, para a "busca" de um "amor reflexivo à vida" admitindo três pressupostos: 1) espiritualidade tem muito a ver com reflexão; 2) a espiritualidade entra em conluio (e não em conflito) com a ciência, e; 3) "a espiritualidade não está de modo algum limitada à religião, muito menos à religião sectária, autoritária” (SOLOMON, 2003, p. 14). A motivação do autor provém de uma crítica ao desvio da filosofia de um amor à sabedoria para um empreendimento "técnico tedioso", e que atrai mais "estudantes com desordens afetivas que aqueles em busca do sentido da vida". Entende que "a f ilosofia não podia ser separada das questões de espiritualidade, e a "religião que realmente tem 
importância, não é apenas um exercício intelectual mas um modo concreto de enfrentar a vida e o mundo" (SOLOMON, 2003, p. 22). Um dos motivos mais instigantes que levaram Solomon a tal empreitada, tal qual narra o próprio, reside no fato de ter se casado com uma católica devota, que pretendia "tornar-se freira um dia" e se tornou uma das "mais conhecidas especialistas em Nietzsche no mundo" [Kathleen Higgins]:

Como todo mundo que conhece mesmo um átimo de filosofia sabe, Nietzsche é o filósofo mais veementemente antirreligioso, anticristão, do cânone ocidental. Kathy conserva e pratica "religiosamente" seu catolicismo, mas isso não a impede de defender o grande filósofo do "Deus está morto". Como o consegue [...] a ideia central, trocada em miúdos, é que seu catolicismo - e seu amor a Nietzsche - consiste em profunda espiritualidade (SOLOMON, 2003, p. 23).

Para o autor, uma espiritualidade que se preze deve ajudar a enfrentar as questões universais que se apresentam na vida, como a "necessidade pessoal e coletiva de entender com clareza nosso lugar no mundo", como devemos viver e como deveríamos enfrentar dificuldades e tragédias esmagadoras na vida? Como deveríamos pensar a morte e como lidar com ela? (SOLOMON, 2003, p. 25; 2829). Seguindo Hegel, entende a natureza como espiritual, sendo portanto, a espiritualidade a "natureza plenamente desenvolvida em nós" e ajuda a filosofia a deixar de ser mera teoria do conhecimento (SOLOMON, 2003, p. 31). Porém, é a compreensão que "não há respostas definitivas [e não há formulação de perguntas] que nos introduzam na esfera da espiritualidade", pois "mesmo que partilhemos um dogma com milhões, as questões permanecem e cada um encontra a sua resposta" não sem ter que descobrir as "paixões nobres e reflexivas da vida” para realizar uma "vida vivida em conformidade" com elas. Assim, a espiritualidade como um "amor reflexivo à vida" ajuda a encarar o destino com serenidade e enxerga a vida como dádiva, "até como um milagre" diante do assombro da vida, "contanto que isso não seja usado como desculpa para fechar a porta à curiosidade e à indagação científica” (SOLOMON, 2003, p. 32-49). A postura cética ao sobrenatural de Solomon implica que a espiritualidade naturalizada "significa insistir que esta vida, com todas as suas alegrias e atribulações, é a única em 
que vale a pena pensar" sendo sua tarefa um pensar quepermita o assombro de dimensões fundamentais da vida, vendo a espiritualidade como paixão, confiança cósmica, racionalidade das emoções, enfrentamento da tragédia e do fatalismo, bem como assimilação da dimensão social da morte, como um aprender a morrer com dignidade, na medida em que traça o tempo de aprendizagem da valorização da vida. A espiritualidade é um processo, mais que um resultado, e a literatura ajuda a manter esse processo (SOLOMON, 2003, p. 118; 290).

Comte Sponville chama de imanensidade essa capacidade de contemplar a imensidade do universo que se exprime em uma "imanência inesgotável", e que propicia a sensibilidade à percepção de uma realidade convidativa à comunhão com esse Todo e com as pessoas. Tal beleza é portadora de serenidade para o coração e encontrar a alegria na saída de si ao encontro desse Todo. Neste tempo em que a vida se apresenta não raro como sem sentido, ciente de não ter garantias, cheia de ansiedade e medo diante da imprevisibilidade da vida, inúmeras rotas de fuga se apresentam como oportunidades mercadológicas. É aqui que o filósofo recusa a fé em Deus para adotar uma postura de busca de lucidez, tendo início pela solidão como momento de olhar para as angústias que lhe são próprias e reconhecer o desespero. Para chegar a esta solidão, é necessário a coragem que vai vencendo esse "tempo de desespero" e a espiritualidade vai sendo fonte de serenidade para a alma humana adquirir lucidez, ao reduzir o narcisismo diante da imanensidade do universo (COMTE-SPONVILLE, 2006, p. 7-14).

Sendo atraído para a profundidade da vida face as banalidades do cotidiano, emerge a coragem de realizar o mistério do ser pelo domínio de si e do medo, e cultivar virtudes que atuam como "força da alma" (COMTE-SPONVILLE, 2004, p. 52-57). A espiritualidade é, portanto, o que permite o acesso ao mistério do ser, ao humor que integra as contradições e relativiza a mediocridade, à compaixão e a misericórdia que produz o horror diante do mal e alargam a compreensão humana, ao sair de si, sob a forma de desinteresse e altruísmo. Contudo, em um mundo niilista, que carece de sentido e esperança, a verdade está "ao lado do ser” e não "do lado do discurso". É necessário a coragem do silêncio. A verdade é, portanto, 
"silêncio" (COMTE-SPONVILLE, 2000, p. 185), no qual se pode mergulhar nessa mística contemplativa que desvela que somos capazes da beleza do amor e da ética (2007, p. 116).

\section{A natureza poética da espiritualidade}

Entre as propostas de teorização, independentemente de ser uma recusa radical das tradições religiosas (Comte-Sponville e Solomon) ou de releituras das mesmas (Frankl e Corbí) há um consenso em reconhecer uma dimensão de Mistério presente na vida que permite o ser humano acessar sua profundidade e humanizar sua condição. Se entende aqui que a recusa das religiões está mais ligado à recusa de mentalidades moldadas em teodiceias, enquanto estas substituem o que Frankl chamou de patodiceia ou o que chamamos de teopatodiceias elaboradas a partir das experiências místicas dos grandes fundadores das religiões. Tal processo substitue a sabedoria pelo controle social, tal qual Corbí aponta, e que em Comte-Sponville e Solomon tais distinções não ocorrem, sendo antes um pressuposto constitutivo do modo religioso de pensar.

As experiências místicas fundacionais, enquanto experiência dos grandes fundadores, resultam em um segundo momento em mistagogia, enquanto arte de conduzir outros a fazerem a mesma experiência e constitui o cerne de uma tradição religiosa enquanto experiência de sentido que inaugura projetos axiológicos coletivos (CORBÍ, 2013). Tais mistagogias são produtoras de: 1) uma literatura religiosa (escrita ou narrada) em que se pode ter contato com a experiência fundante; 2) um universo simbólico advindo da literatura produzida, que doa símbolos ao universo ritual e alimenta a experiência; 3) uma elaboração sapiencial, enquanto tarefa teológica ou filosófica da tradição religiosa; 4) uma ampliação da consciência ética que categoriza tal tradição como religião axial. Tal fase mistagógica, enquanto processo amplificador da experiência fundacional e inauguradora de uma tradição, por sua capilaridade social sempre incorre no risco 
de ser cooptada por um regime político, e se tornar uma religião oficial de um determinado espaço geográfico, tornando-se assim uma teocracia, sendo este o processo histórico pelo qual passaram as grandes tradições religiosas. Em uma teocracia, os elementos mistagógicos sofrem sérios reducionismos como: 1) a redução de axiomas ou verdades fundamentais (no Ocidente conhecido como dogma) de uma tradição que contém uma sabedoria de vida para um dogmatismo, enquanto imposição de ideias; de ritos enquanto momentos reavivadores da experiência fundacional, para um ritualismo, enquanto imposição esvaziada de significação dos mesmos; e do natural desdobramento da consciência ética para um moralismo, enquanto imposição de costumes. A manutenção cultural de tais reducionismos é resultado da criação das teodiceias enquanto justificativas divinas que passam a regular a sociedade. Toda teocracia cria suas teodiceias, e mesmo que as teocracias cheguem a falência, as teodiceias permanecem mais tempo na cultura.

Contudo, mesmo nas sociedades agrárias as teodiceias sofrem recusas mesmo, bem como nada impede que irão continuar a existir nas sociedades de inovação, na medida em que legitimam ordens sociais. Neste sentido, e diferentemente de Corbí, ainda que sendo um comentário crítico empático tal qual Moreira (2010), mesmo os mitos são revisitados nas sociedades antigas. Na Ilíada, há uma teodiceia, por exemplo, pois as causas da Guerra de Tróia são atribuídas a vontade divina, pois é fruto de uma disputa entre Éris, Afrodite e Atenas, ao passo que na Odisseia a causa da guerra é a obstinação do desejo desmedido pelo poder na Casa de Atreu, presente no mito de Tântalo. Há dentro da obra homérica um movimento de recusa da teodiceia (AUBRETON, 1968, p. 223-255) para uma redescoberta da patodiceia, na medida em que Ulisses deseja retornar ao lar, enfrentando Posseidon, e recebendo a mediação exclusiva de Atenas, havendo já ali uma espiritualidade amiga da sabedoria, que antecede o iluminismo grego de Heródoto. Ainda vale dizer que se a consciência grega passou por uma historicização do mito, a consciência ética hebraica, crítica a monarquia e sua respectiva teodiceia legitimadora, foi mitologizando a histórica como recurso de conscientização profética (RICOEUR, 2006, p. 247-266). 
A mentalidade de teodiceia além de substituir progressivamente a consciência de Mistério, vai anestesiando a consciência trágica e de responsabilidade humana, de modo que a recusa de Deus do ateísmo tradicional é a recusa da teodiceia, e do ateísmo contemporâneo o fundamentalismo como efeito cultural último das teodiceias, enquanto reavivamento afetivo sob a mesma chave hermenêutica, alvo direto dos oportunismos políticos imbuídos de discursos religiosos. Com efeito, o que tem se chamado de espiritualidades não religiosas se constituem, ao menos em grande parte como recusa de tais reducionismos oriundos de uma teodiceia que anula o indivíduo, entretanto, se nos parece que o problema não reside no fato de haver ou não instituições religiosas, mas na capacidade de produção e reprodução de teodiceias antigas e modernas.

Nesse sentido a recuperação da mística ou da espiritualidade podem ser insuficientes na medida em que podem reforçar mentalidades de teodiceia, estando estas dentro ou fora das instituições religiosas, na medida em que são mentalidades presente nas culturas. Um fenômeno bastante expressivo das teodiceias presente nas culturas é o sentimento religioso que se manifesta em épocas de Copa do Mundo, em que as torcidas rezam piedosamente para obter a vitória do seu time, tal qual Zeus decidia o destino das Olimpíadas.

Com efeito, a recuperação da categoria Mistério reabilita a epistemologia axiológica, ao invés do Ser ou Deus enquanto objeto de observação da metafísica essencialmente grega como fundamento da pólis pelo modelo platônico totalitarista de Estado. Tal enfoque redimensiona as nomeações divinas como sendo sempre insuficientes, sendo o místico enquanto poeta do Mistério aquele que melhor cumpre tal tarefa, pois seu mirandum aponta para a realidade. $\mathrm{O}$ místico assim não define um conceito, mas é aquele que descobre um modo de dar sentido à vida, e sua experiência é constitutiva, sendo a poesia um locus revelationis. Essa natureza poética da espiritualidade (ROBLES, 2010) é um elemento de uma autêntica espiritualidade, religiosa ou não, porque é própria do místico, na medida em que converge para a descoberta de uma beleza na vida, que a motive e a inspire, por 
des-cobrir dimensões mais profundas e significativas para além de sua finitude e vicissitudes, sendo tal espiritualidade humanizadora do humano e criadora de projetos coletivos axiológicos, ao mesmo tempo que a poesia também comporta a profecia, motivo da expulsão dos poetas da pólis. Assim, identificar a natureza poética das espiritualidades não religiosas ou das espiritualidades ligadas as tradições religiosas pode colaborar com projetos axiológicos coletivos que não se limitam a religiosos ou não religiosos, mas a uma cultura que depura os elementos de teodiceia, e resgata a busca de sentido, com uma espiritualidade que afirme o humano e integre a beleza do mistério à consciência histórico crítica. Toda poesia é religiosa, sendo religiosa ou não, na medida em que é autenticamente desveladora de humanidade, da beleza humana de transcender suas contradições pessoais e sociais. Para expressar tal natureza poética da espiritualidade, enquanto afirmação do humano optou-se pela apresentação de um autor, no mínimo insuspeito, porém que corrobora com a tarefa comum de espiritualidades religiosas e não religiosas.

\section{Poesia e a espiritualidade não religiosa em Sartre}

Para Jean Paul Sartre, qualquer forma de determinismo passa por sua formulação de linguagem objetiva, conceitual, pretensamente definitiva e suficiente para instituir um padrão de valores e uma definição de sociedade. A linguagem, portanto, cria a doutrina e esta fundamenta a sociedade por meio da ideologia, que tende a moldar o indivíduo em um paradigma. Deste modo, a linguagem é utilizada para instituir determinismos e definir padrões de sociedade que desconsideram a importância do sentido da vida do indivíduo. Assim em Que é a literatura? começa se perguntando: Que é escrever?

A poesia, diferentemente, tal qual descrita pelo filósofo existencialista, "não se serve das palavras" mas "antes as serve. Os poetas são homens que se recusam a utilizar a linguagem”. A relação do poeta com a linguagem não se dá pelo uso dos significados em função da definição da verdade, mas antes escutam a realidade mesma da verdade que se recusa ser definida, e portanto, não manipulável, e sim revelável: 
É na linguagem e pela linguagem concebida como uma espécie de instrumento, que se opera a busca da verdade, não se deve imaginar que os poetas pretendem discernir o verdadeiro, ou dá-lo a conhecer. Eles tampouco aspiram a nomear o mundo, e por isso não nomeiam nada, pois a nomeação implica um perpétuo sacrifício do nome ao objeto nomeado, ou, para falar como Hegel, o nome se revela inessencial diante da coisa esta, sim, essencial. Os poetas não falam, nem se calam: trata-se de outra coisa (SARTRE, 2004, p. 13).

O poeta se recusa a uma relação de "linguagem-instrumento" que domestica a linguagem, ao passo que a poesia olha para a linguagem como viva, em seu "estado selvagem". A "atitude poética" considera as palavras como "coisas" e não como "signos":

A ambiguidade do signo implica que se possa, a seu bel-prazer, atravessála como a uma vidraça, e visar através dele a coisa significada, ou voltar o olhar para a realidade do signo e considerá-lo como objeto. O homem que fala está além das palavras, perto do objeto; o poeta está aquém (SARTRE, 2004, p. 14).

Aquele que faz uso da linguagem enxerga nas palavras o que está procurando para seus objetivos, o poeta ouve as palavras, e é interpelado por elas. Para o primeiro as trata como "convenções úteis", "instrumentos que vão se desgastando pouco a pouco e são jogados fora quando não servem mais”. Já para o poeta as palavras são vivas, o qual se funde a elas, pois "o significado também é coisa, incriada, eterna" (SARTRE, 2004, p. 14). O "falante" está situado na linguagem, "em situação de linguagem" (SARTRE, 1948, p. 19) como prolongamento de seus sentidos, e as "manipula de dentro" como um "corpo verbal" em que está rodeado e "do qual mal tem consciência”. O poeta está "fora da linguagem" e "vê as palavras do avesso, como se não pertencesse à condição humana" e vê, mesmo no uso das palavras para se comunicar, uma barreira, dado o modo utilitário que o falante faz dela, sem certa veneração. O poeta não conhece as coisas por seus nomes, mas tem com elas um "primeiro contato silencioso" e em seguida se aproxima "tocando-as, tateando-as, palpando-as" e nelas "descobre uma pequena luminosidade própria e afinidades particulares com a terra, o céu, a água e todas as coisas criadas", porém as palavras "não o lançam para fora de 
si mesmo" mas "para o meio das coisas", no "meio do mundo" pois a linguagem inteira é para o poeta o "espelho do mundo", algo como que uma "armadilha para capturar uma realidade fugaz" . É a partir da "imagem" do significado que o "representa" que o significado é "realizado" no poeta e assim, se estabelece entre a "palavra e a coisa significada” uma "dupla relação recíproca de semelhança, de mágica e de significado" (SARTRE, 2004, p. 14-15).

A palavra não está simplesmente presa a uma definição objetiva, mas passa a ser um acontecimento na subjetividade do poeta que adentra no ser da linguagem, e ali se lhe é revelado ao poeta, "como um espelho" a "sua própria imagem" (SARTRE, 2004, p. 16). As palavras, para o poeta, “já não são dele”, mas ele se percebe no espelho das coisas que refletem "o céu, a terra e a própria vida”, e se torna junto com elas as próprias coisas a partir do significado que ilumina o “coração negro das coisas” (SARTRE, 1948, p. 16). A poesia provoca uma interrogação que "não comporta resposta”, mas antes é sua própria resposta, é a "interrogação tornada coisa". A poesia lança a vida em uma "existência interrogativa”, e por isso mesmo, capaz de alcançar o absurdo do nada, e não sendo feita para a resposta, a mesma existência interrogativa prossegue sua contínua procura de um sentido para o absurdo da vida. Por isso mesmo é redundante falar de um "engajamento poético", pois o engajamento com a coisa da realidade é parte do "microcosmo da poética": "Compreende-se facilmente a tolice que seria exigir um engajamento poético. Sem dúvida a emoção, a própria paixão - e por que não a cólera, a indignação social, o ódio político - estão na origem do poema”. Para o filósofo, a crise social do início do século XX, que inclui a “crise da linguagem” é uma “crise poética” (SARTRE, 2004, p. 17), pois perde a consciência humana seu eterno descontentamento da existência rumo a busca. A atitude poética, por sua vez, está no lugar de um "sistema transcendente de valores” e sua "contemplação inofensiva" na indagação do que "vale a pena" nesse absurdo da existência para fazer do "falar" um "agir". Ao "nomear" a conduta do indivíduo, "ele se vê" e sabese "sendo visto" e assim "passa a existir" e "assume dimensões novas". Em cada busca poética da palavra há um "desvendamento" da existência em que a pessoa se "engaja” um pouco mais "no mundo" e passa a "emergir" dela "um pouco mais" 
na direção do porvir reduzindo a recusa desse engajamento (SARTRE, 2004, p. 20).

Há com isso, no pensamento sartreano, uma espécie de mística da poesia no qual é preciso uma atitude de busca de “des-vendar" o enigma de si para além das palavras que o definem, pois a situação de linguagem é própria da realidade humana que o limita, mas ao mesmo tempo permite ir além: "Deus, se existisse, estaria como bem viram certos místicos, em situação de linguagem, em relação ao homem”. Enquanto as palavras permanecem apáticas elas não são significativas e não permitem tomar a consciência do ser, ou seja, do sentido da existência sendo por isso incapazes de transpor o falar para o agir: "É no amor, no ódio, na cólera, no medo, na alegria, na indignação, na admiração, na esperança, no desespero que o homem e o mundo se revelam em sua verdade” (SARTRE, 2004, p. 21). O poeta é aquele que desvenda o "mundo" e especialmente "o homem para os outros homens" para que assim assumam sua "responsabilidade", deixando de "ignorar o mundo" e "considerar-se inocente diante dele".

Além de desvendar o que é escrever, o filósofo se pergunta para que escrever? $\mathrm{O}$ escritor engajado com a realidade sabe que a palavra é ação e que desvendar é mudar, mas é possível que o leitor se mantenha em sua “obstinação”, mesmo "com conhecimento de causa" (SARTRE, 2004, p. 19-20). Para Sartre a perda da consciência disso que chamamos de "mística" atitude poética conduz os meros falantes e mesmo críticos literários a tornarem-se uma espécie de "hereges cátaros" da linguagem, pois "não querem ter nada a ver com o mundo real” e toda a literatura nada mais é que uma "vasta tautologia" inventando uma maneira de "falar para não dizer nada" (SARTRE, 2004, p. 25). Para a mística que o poeta tem com a linguagem as palavras são "transparentes" e o olhar do poeta "as atravessa" exatamente por indagá-las, e nelas a realidade. Para essa existência interrogativa que permite inventar a existência, a palavra é um "vidro opaco" entre a linguagem e o olhar interrogativo, e a tautologia das palavras não permite transpor a barreira da linguagem e atingir o ser, o sentido do existir em nome de um purismo, por isso 
para Sartre, “a arte nunca esteve do lado dos puristas” (SARTRE, 2004, p. 23).

Há uma perda da paixão que provoca a interrogação da existência com essa crise poética de modo que as ideias se tornaram “insossas” ao longo dos séculos e permanecem como "pequenas obstinações pessoais". Há que se ir além das "razões da razão, que esmaecem" para que se perceba "as razões do coração, a virtude, os vícios" e a "grande dor que os homens tem de viver". Tais ideias insossas e opacas não permitem o indivíduo enxergar a realidade mais profunda, e o fazem agir com a má fé de se reconhecer como superior por ter acesso a essas ideias, com a mesma "superioridade que os cães vivos tem sobre os leões mortos" (SARTRE, 2004, p. 26-27).

A missão de escrever, portanto, está em função da consciência de que a realidade humana é "desvendante" e o ser humano é "o meio pelo qual as coisas se manifestam" e por isso um dos principais motivos da criação artística é a “necessidade de nos sentirmos essenciais em relação ao mundo". O escritor deve fazê-lo de modo que sempre o próprio escritor se sinta surpreso, pois o texto poético não está em função de definir, mas de tirar as vendas da realidade humana, que só é possível quando o "impulso criador vier do mais fundo do coração" (SARTRE, 2004, p. 35). A literatura provoca a dialética do tempo entre aquilo que é a realidade e o que pode ser, voltando-se para o leitor como um "apelo à sua liberdade" para uma atitude de deslocamento do futuro aproximado na ação provocada pelo texto. A literatura é o modo por excelência de intersubjetividade:

A operação de escrever implica a de ler, como seu correlativo dialético e esses dois atos conexos necessitam de dois agentes distintos. É o esforço conjugado do autor com o leitor que fará surgir esse objeto concreto e imaginário que é a obra do espírito. Só existe arte por e para outrem [...] o leitor tem consciência de desvendar e ao mesmo tempo de criar; de desvendar criando, de criar pelo desvendamento. [...] o objeto literário, ainda que se realize através da linguagem, nunca é dado na linguagem; ao contrário, ele é, por natureza, silêncio e contestação da fala. Do mesmo modo, as cem mil palavras alinhadas num livro podem ser lidas uma a uma sem que isso faça surgir o sentido da obra; o sentido não é a soma das palavras mas sua totalidade orgânica. Nada acontecerá se o leitor não se colocar, logo de saída e quase sem guias, à altura desse silêncio. Se não o inventar, em suma, se não introduzir e mantiver nele as palavras e as frases que desperta (SARTRE, 2004, p. 36-38). 
A intersubjetividade se dá como invenção de si a partir do espelho do olhar do outro presente no texto, como apelo à liberdade do leitor, em que o sentido da obra é oferecido como sentido a ser descoberto.

\subsection{Silêncio e escuta poética}

O caminho do silêncio é necessário para penetrar na escuta ao que está velado, e a descoberta implica uma adesão do leitor:

O silêncio de que falo é, de fato, o fim visado pelo autor, pelo menos este jamais o conheceu; seu silêncio é subjetivo e anterior à linguagem, é a ausência de palavras, é o silêncio indiferenciado e vivido da inspiração, que a palavra particularizará em seguida. É preciso que o leitor invente tudo, num perpétuo ir além da coisa escrita. Sem dúvida, o autor o guia, mas somente isso; as balizas que colocou estão separadas por espaços vazios, é preciso interligá-las, é preciso além delas. Em resumo, a leitura é criação dirigida (SARTRE, 2004, p. 38).

O autor guia o leitor à escuta do texto solicitando sua subjetividade a partir daquilo que lhe afeta, de modo que solicita deste suas emoções e a estas uma ação, que por sua vez oferece a possibilidade, não somente de participar da vida da obra, mas antes de dar vida à obra:

O objeto literário não tem outra substância a não ser a subjetividade do leitor: a espera de Raskolnikoff é a minha espera, que eu empresto a ele; sem essa impaciência do leitor não restariam senão signos esmaecidos; seu ódio contra o juiz que o está interrogando é o meu ódio, solicitado, captado pelos signos, e o próprio juiz não existiria sem o ódio que sinto por ele através de Raskolnikoff; é esse ódio que o anima, é a sua própria carne. Mas, por outro lado, as palavras estão ali como armadilhas, para suscitar nossos sentimentos e fazê-los reverter sobre nós; cada palavra é um caminho de transcendência, dá forma e nome às nossas afeições (SARTRE, 2004, p. 38s).

No capítulo destinado Para quem escrever? o próprio Sartre levanta a pergunta se este leitor pode ser "universal". Se o autor se dirige a todos os homens, e estes vivem tantas realidades distintas, como afetá-lo pela leitura? A liberdade do leitor não é "pura” e é necessário que a "limpe” da tentação das "liberdades 
atoladas, mascaradas, indisponíveis”. É para limpar essa liberdade que o autor escreve, e assim o faz, pois a sua própria liberdade não é "tão pura”, de modo que escrever é o próprio exercício de purificar também a liberdade do autor. "Toda obra literária é um apelo", e solicita a liberdade do leitor para colaborar na missão de sua obra, exatamente no que a liberdade do leitor tem de "mais puro". O apelo é também um voto de confiança na liberdade do leitor:

Uma vez que a criação só pode encontrar sua realização final na leitura, uma vez que o artista deve confiar a outrem a tarefa de completar aquilo que iniciou, uma vez que é só através da consciência do leitor que ele pode perceber-se como essencial à sua obra, toda obra literária é um apelo. Escrever é apelar ao leitor para que este faça passar à existência objetiva o desvendamento que é empreendimento por meio da linguagem (SARTRE, 2004, p. 39).

Há uma cumplicidade crescente na medida em que a obra vai solicitando uma atitude do leitor, que por sua vez vai se identificando com a vontade de existir, oferecida pelo autor na obra:

$\mathrm{O}$ livro não serve à minha liberdade, ele a requisita. Com efeito, não seria possível dirigir-se a uma liberdade enquanto tal pela coerção, pela fascinação ou pelas súplicas. Para atingi-la, há apenas um método: primeiro reconhecê-la, depois confiar nela; por fim, exigir dela um ato, em nome dela própria, isto é, em nome dessa confiança que depositamos nela. Assim, o livro não é, como a ferramenta, um meio que vise a algum fim: ele se propõe como fim para a liberdade do leitor (SARTRE, 2004, p. 40).

Quem promove essa cumplicidade é o personagem que empresta do leitor suas paixões, na medida em que aceita os apelos feitos pelo próprio personagem, que o autor deu vida. A obra de arte é valiosa exatamente por sua capacidade de ser um apelo a uma maior humanidade. O pacto que se estabelece entre autor e leitor se chama leitura. O leitor não é obrigado a abrir o livro, mas aberto, a leitura é um exercício de generosidade, e esta é já uma “afeição”. Algo o moveu a isso, e este algo corresponde ao que pode responder sua vontade de existir. Os sentimentos provocados são reveladores de si mesmo ao próprio leitor:

As afeições do leitor nunca são dominadas pelo objeto, e como nenhuma realidade exterior pode condicioná-las, tem sua fonte permanente na 
liberdade, isto é, todas são generosas - pois chamo de generosa uma afeição que tem a liberdade por origem e por fim. Assim, a leitura é um exercício de generosidade; e aquilo que o escritor pede ao leitor não é a aplicação de uma liberdade abstrata, mas a doação de toda a sua pessoa, com suas paixões, suas prevenções, suas simpatias, seu temperamento sexual, sua escala de valores. Somente essa pessoa se entregará com generosidade; a liberdade a atravessa de lado a lado e vem transformar as massas mais obscuras da sua sensibilidade. E como a atividade se fez passiva, para melhor criar o objeto, reciprocamente a passividade se torna ato; o homem que lê se eleva ao plano mais alto. Eis por que vemos pessoas reconhecidamente duras verterem lágrimas diante do relato de infortúnios imaginários; por um momento elas se tornam aquilo que seriam se não tivessem passado a vida mascarando a própria liberdade (SARTRE, 2004, p. 42).

Assim a liberdade é um pacto de generosidade na confiança que o autor tem no leitor e este no autor, de modo crescente na medida em que avança na leitura. Essa confiança dilata a liberdade na cumplicidade da responsabilidade mediante aquilo que se viveu na leitura, e assim realiza a intersubjetividade não somente entre autor e leitor, mas entre esses dois e a História da realidade humana, no mundo. É o sentimento de transformar o mundo que permite "sentir-se nele". Aí está a "arte do autor" em levar o leitor a "criar" àquilo que "desvenda". O pacto vai se firmando pelo "reconhecimento da liberdade por si própria" e sua consequente "alegria". Essa "alegria estética" provém de uma interiorização e acompanha a consciência de que o "mundo é um valor" e uma "proposta à liberdade humana" que Sartre chama de "modificação estética do projeto humano" e vê o mundo como "minha tarefa". A leitura faz do livro um "acontecimento novo" que "envolve realmente a totalidade harmoniosa das liberdades humanas", em função da invenção da existência e da História a fim de que o mundo possa ser "impregnado de liberdade", sempre e cada vez mais:

Assim, o universo do escritor só aparecerá em toda a sua profundidade no exame, na admiração, na indignação do leitor; amor generoso é promessa de manter, e a indignação generosa é promessa de mudar, e a admiração é promessa de imitar; é certo que a literatura é uma coisa e a moral é outra bem diferente, mas no fundo do imperativo estético discernimos o imperativo moral (SARTRE, 2004, p. 49-51).

O próprio Sartre faz menção a esse modo de percepção como proveniente 
dos "místicos", de modo que mesmo "Deus, se existisse" não escaparia desta condição, de ser desvendado para além de frias palavras (SARTRE, 1948, p. 28). A busca do poeta não opera pela razão cartesiana, mas seu cogito segue a intuição e a inspiração, como pistas da transcendência deixadas nos vestígios da literatura para desvendar o mundo e, sobretudo "os outros homens" de modo a mover o indivíduo da "inocência" ao "engajamento", coincidindo assim com os autores supracitados. O poeta dá voz as "razões do coração", de onda brota o "impulso criador". A leitura da obra literária é um ato de fé em que a liberdade se deixa ser conduzida pela vontade de sentido, tal qual se deixa guiar Cristo em sua Paixão:

Esses sentimentos são de uma espécie peculiar: têm a liberdade como origem; são dados por empréstimo. Toda crença é livremente consentida, mesmo aquela que deposito na narrativa. Trata-se de uma Paixão, no sentido cristão da palavra, isto é, uma liberdade que se coloca resolutamente em estado de passividade, a fim de obter, por esse sacrifício, um certo efeito transcendente. O leitor se faz crédulo, desce até a credulidade e esta, embora acabe por se fechar sobre ele como um sonho, é acompanhada a cada instante pela consciência de ser livre (SARTRE, 2004, p. 42).

O leitor professa sua leitura no projetar da existência. O leitor que crê no poeta autor, em dinâmica de existência interrogativa não se limita à barreira do signo, mesmo que já o conheça, mas mergulha para além dele, respondendo à sua "intuição racional” ao que Kant reserva à "Razão divina”:

A obra só existe na exata medida das suas capacidades; enquanto lê e cria, sabe que poderia ir sempre mais adiante em sua leitura, criar mais profundamente; com isso a obra lhe parece inesgotável e opaca, como as coisas. Essa produção absoluta de qualidades que, à medida que emanam da nossa subjetividade, se imobilizam diante dos nossos olhos como objetividades impermeáveis, nós a aproximaríamos de bom grado daquela "intuição racional" que Kant reservava à Razão divina (SARTRE, 2004, p. 39).

\section{Conclusão}

No cenário brasileiro, se nos parece que há uma postura crítica às instituições, mais que uma recusa delas, uma recusa do que aqui se chamou de formas de teodiceia na cultura. Âmbito em que o surgimento das espiritualidades 
não-religiosas como não-recepção de tais reducionismos, sob a figura de formalismos anacrônicos e discursos legitimadores de práticas e mentalidades totalitárias, se tornam extremamente pertinentes e elementos depuradores das tradições religiosas, enquanto recuperam a qualidade de vida humana, núcleo antropológico destas tradições. Tais teodiceias são formas teóricas no qual as espiritualidades religiosas são amalgamadas na medida em que as religiões se tornam reguladoras da sociedade, especificamente quando se tornam aparatos teóricos das teocracias, repercutindo no tecido cultural, e consequentemente no modo de pensar a questão religiosa.

Contudo, não nos parece que as tradições religiosas estejam superadas, pelo simples fato de que a religião pode sempre, até mesmo em uma sociedade de inovação, ser um elemento potencial de justificação da realidade, tal qual se manifesta nas novas formas de espiritualidade bastante vivas inclusive. Isso exige que a questão religiosa seja tratada também como uma questão social, sob risco de se tornar um ponto cego na cultura, e assim sendo, tornar-se instrumento de manobras políticas. Ademais, vale lembrar a análise que o filósofo francês Pierre Lévy (2011, p. 12-14) faz da cultura do século XX sobre o mau uso da abstração como capacidade de hipostasear macroentidades que se tornam objeto de nossas teorizações como a Economia, a Filosofia, a Religião, a Ciência, a Esquerda, a Direita e desta maneira não se considera os agentes efetivos que são indivíduos situados no tempo e no espaço, vulneráveis às paixões, ao poder, à ganância, assim como por detrás destas macroentidades há também pessoas de bem, críticas e lucidas, de modo que a reflexão a partir destas abstrações não permite identificar os verdadeiros sujeitos, passando assim a uma lógica de rótulos que impede o diálogo efetivo e a discussão pertinente.

Neste sentido, identificar o elemento poético das espiritualidades ou a natureza espiritual da poesia, em sentido amplo pode ajudar no diálogo entre as espiritualidades não religiosas e religiosas na tarefa de recuperar as sabedorias contidas nas tradições, e integrar a consciência crítica em um Estado laico, não 
somente como respeitadora da liberdade religiosa, mas cooperativa entre homens e mulheres, sem que as diferenças sejam obstáculos para o bem comum. Deste modo a poesia pode ser depuradora das teodiceias, e recuperar a espiritualidade humana de se reinventar constantemente, quer seja não nomeando o absoluto, enquanto patodiceias, quer seja nomeando tal mistério, enquanto aquilo que chamamos de teopatodiceias enquanto revisita as tradições religiosas, e neste sentido, se aproxima a proposta de Corbí e de Frankl.

Assim, falar de uma espiritualidade não religiosa em Sartre pretendia aqui mostrar a natureza espiritual da poesia. O "místico" sartreano por excelência é o poeta, que não usa as palavras, mas se relaciona com elas, sobretudo deixa-se ser interpelado pelo ser da linguagem que ali se esconde. Pela poesia se penetra no mistério do mundo, se experimenta “os sabores" das coisas e dispõe a vida em dinâmica de incessante busca, de "existência interrogativa”. O poeta, diz o filósofo ateu, retira as palavras da "condição humana e o convida a considerar, com os olhos de Deus, o avesso da linguagem" (SARTRE, 2004, p. 14-18). O olhar do poeta, contudo não é "pura contemplação", mas contemplação da realidade que pede um sentido que só pode emergir da [re]invenção de si a partir do outro, não somente mediada mas inspirada pela linguagem na medida em que aprende com o poeta a penetrar silenciosamente no mistério da linguagem. O silenciamento é uma tarefa de se despir do próprio olhar, para olhar o outro com o olhar do outro, sendo a poesia este exercício de alteridade, que desvela a si próprio o dever da liberdade de seus condicionamentos que manipulam o outro e se escusa de sua responsabilidade, ou seja, de sua má fé (SARTRE, 2002, p. 318-319). A proposta sartreana de viver como "fundamento sem fundamento" equivale a categoria desfundado em Corbí, enquanto ser não determinado por nada em princípio, mas sujeito da história para decidir o seu projeto de vida. Em ambos, coincide com a recusa de definições arbitrárias, presentes nas teodiceias: "o homem é apenas seu projeto, só existe na medida em que se realiza, ele é tão somente o conjunto de seus atos” (SARTRE, 1978, p. 55). Liberdade aqui é a tarefa de ser livre para decidir pelo que dá sentido à própria vida, superando os condicionamentos e contradições pessoais. 
A poesia, poderia se dizer, é uma mística humana do desvendamento de sua condição em direção à liberdade, provocada pela necessidade de dar sentido à existência, se pondo em busca como existência interrogativa e assim encontra inspiração para a ação inventiva e transformadora do mundo. Espiritualidade e poesia são convergentes, sendo religiosas ou não, por ser a leitura desta última um ato de fé no humano.

\section{REFERÊNCIAS}

AUBRETON, R. Introdução a Homero. São Paulo: Editora USP, 1968.

COMTE-SPONVILLE, A. O espírito do ateísmo: introdução a uma espiritualidade sem Deus. São Paulo: WMF Martins Fontes, 2007.

COMTE-SPONVILLE, A. Pequeno tratado das grandes virtudes. São Paulo: WMF Martins Fontes, 2004.

COMTE-SPONVILLE, A. Tratado do desespero e da beatitude. São Paulo: WMF Martins Fontes, 2006.

COMTE-SPONVILLE, A. Viver. São Paulo: WMF, 2000.

CORBÍ. M. Análisis Epistemlógico de las configuraciones axiológicas humanas. Salamanca: Ediciones Universidad de Salamanca, 1983.

CORBÍ. M. La construcción de los proyectos axiológicos coletivos: Princípios de Epistemologia Axiológica. Barcelona: Cetr Editoral/Bubok Publishing, 2013.

CORBÍ. M. Para uma espiritualidade leiga: Sem crenças, sem religiões, sem deuses. São Paulo: Paulus, 2010a.

CORBÍ. M. Nada de mí. CETR, Barcelona, 2010b. Disponível em:

<http://cetr.net/es/articulos/calidad_humana/nada_de_mi >. Acesso em: 20 abr. 2014.

CORBÍ. M. Religión sin religión. Madrid: PPC, 1996.

DUBET, François. Le Declin de L'Institution. Paris: Edition du Seuil, 2002.

FRANKL, V. A Presença Ignorada de Deus. 8. ed. São Leopoldo: Sinodal/ Petrópolis: Vozes, 2004.

FRANKL, V. Em Busca de Sentido: Um Psicólogo no Campo de Concentração. 21. ed. São Leopoldo: Sinodal/ Petrópolis: Vozes, 2005. 
FRANKL, V. Psicoterapia e Sentido da Vida. 4. ed. São Paulo: Quadrante, 2003.

GOIS, A.; SCHWARTSMANN, H. Cresce o número de evangélicos sem ligação com igrejas. Folha de São Paulo, São Paulo, 15.ago.2011. Disponível em:

<http://www1.folha.uol.com.br/fsp/poder/po1508201102.html>. Acesso em: 15 abr.2014.

IBGE - Instrituto Brasileiro de Geografia e Estatísticas. Dados do censo. 2010. Disponível em: <http://www.sidra.ibge.gov.br/bda/tabela/listabl.asp?>. Acesso em: 2 maio 2014.

LÉVY, P. As tecnologias da inteligência. São Paulo: Editora 34, 2011.

LUCKMANN. A religião invisível. São Paulo: Loyola/Olho d’água, 2014.

MOREIRA, A. S. Religiosidade laica: uma introdução ao pensamento de Marià Corbí. Horizonte, Belo Horizonte, v. 8, n. 19, p. 21-40, 2010.

RIBEIRO, F. S. Senso religioso contemporâneo: Proposição de uma epistemologia axiológica para um tempo de crises. Anais da ABHR, São Luís, v. 13, 2012. Disponível em: <http://www.abhr.org.br/plura/ojs/index.php/anais/article/viewF-le/661/551>. Acesso em: 20 abr. 2014.

RIBEIRO, J. C. Sem religião no Brasil: Dois estranhos sob o guarda-chuva. Cadernos IHU Ideias, São Leopoldo, ano 11, n. 198, 2013. Disponível em:

<http:/www.ihuonline.unisinos.br/cadernos-ihu-ideias/525667-198º-edicao-sem-religiaono-brasil-dois-estranhos-sobre-o-mesmo-guarda-chuva>. Acesso em: 20 Abr. 2014.

RICOEUR, P. A hermenêutica bíblica. São Paulo: Edições Loyola, 2006.

ROBLES, J. A. Naturaleza poética de la espiritualidade: Vista desde la epistemología poética de Octavio Paz. CETR, Barcelona, 2010. Disponível em: <http://cetr.net/files/1402238266_robles_espiritualidad_po-e.pdf>. Acesso em: 20 abr. 2014.

SARTRE, J. P. O existencialismo é um humanismo; A imaginação; Questão de método. São Paulo: Abril Cultural, 1978.

SARTRE, J. P. O ser e o nada: ensaio de ontologia fenomenológica. Petrópolis: Vozes, 2002.

SARTRE, J. P. Que é a literatura? São Paulo: Edições Ática, 2004.

SARTRE, J. P. Que' est-ce que la Litterature? [s.l.]: Éditions Gallimard, 1948.

SOLOMON, R. C. Espiritualidade para céticos: Paixão, Verdade Cósmica e Racionalidade no Século XXI. São Paulo: Civilização Brasileira, 2003.

VILLASENOR, R. L. As práticas religiosas dos "Sem Religião" nas comunidades virtuais. Cadernos IHU, São Leopoldo, ano 11, n. 45, p. 1-67, 2013. Disponível em:

<http://ihu.unisinos.br/images/stories/cadernos/ihu/o45cadernosihu.pdf >. Acesso em: 20 abr. 2014. 